\title{
Mechanical Root-Disruption Practices and Their Effect on Circling Roots of Pot-Bound Tilia Cordata Mill. and Salix Alba L. 'Niobe'
}

\author{
Patrick J. Weicherding, Chad P. Giblin, Jeffrey H. Gillman, David L. Hanson, and Gary R. Johnson
}

\begin{abstract}
Pot-bound Tilia cordata Mill. and Salix alba L. 'Niobe' were planted in a Waukegan silt loam soil in June 2003 at the University of Minnesota TRE nursery in St. Paul, Minnesota. Before planting, the root balls of the container-grown plants were mechanically disrupted using one of three standard root pruning practices recommended to correct circling roots: scoring (slicing), butterfly pruning, or teasing. Root balls on the controls were left undisturbed. The trees were harvested in October 2004. Roots growing beyond the original root ball were counted and measured for diameter growth to assess the effectiveness of the root pruning techniques in encouraging root growth outside of the original root ball. All root disruption treatments resulted in increased fibrous root growth, but no mechanical root disruption method was significantly better than root balls left undisturbed.
\end{abstract}

Key Words. Butterfly pruning; circling roots; girdling roots; mechanical root disruption; pot-bound; root pruning; scoring; slicing; teasing.

A standard planting recommendation for container-grown trees that show evidence of circling roots is mechanical disruption of the root ball before planting (Flemer 1982; Gouin 1983, 1984; Watson and Himelik 1997; Harris et al. 2004). Mechanical disruption of circling roots is typically accomplished at planting by making several vertical cuts down the exterior of the root ball in a practice known as "slicing" or "slashing" (Gouin 1983, 1984; Watson and Himelik 1997; Harris et al. 2004). "Butterfly" pruning (splitting and splaying apart the lower two-thirds of the root ball) has been suggested for planting sites with compacted or poorly drained soils (Gouin 1983; Feucht and Butler 1988; Harris et al. 2004). A less destructive mechanical root disruption practice is to "tease" circling roots out into the surrounding soil at planting. This practice is less common because it is time-consuming (Ellyard 1984).

Mechanical disruption of the root ball before planting is recommended to encourage rapid root development in a radial configuration and to help prevent girdling roots (Blessing and Dana 1987). In early studies, Ingram and van de Werken (1978) and Flemer (1982) reported that undisturbed roots of container-grown plants continue to grow in a circle after transplanting and slowly expand radially into the soil. This was one early theory why container-grown plants often establish poorly when moved to the landscape (Costello and Paul 1975; Flemer 1980; Gouin 1984). Subsequent studies by
Struve and Moser (1984) and Struve (1990), however, have shown that roots circling around in a container do not continue to grow in a circle once the tree is planted in the landscape. The portion of the encircling root that grew in the container does not straighten out, but new growth on this root will not continue to circle if the planting hole offers no resistance (Struve 1990). If this is indeed true, then the time spent mechanically disrupting roots may not be necessary to obtain radial root growth, which eventually occurs on its own.

Girdling roots-roots that compress the woody tissues of another root or stem-may shorten a tree's life by constricting the vascular system and restricting water and nutrient movement and by failing to adequately anchor trees (Gouin 1984; Holmes 1984; Whitcomb 1984; Appleton 1994). Girdling roots may start out as roots that circle on the outside of the root ball in trees grown in containers with slick and/or smooth walls (Appleton 1994). Green-industry professionals have become increasingly concerned with the potential for girdling root development in container-grown trees (Appleton 1993; Siebenthaler 1993) and, as a result, nurseries have changed their in-ground and aboveground production practices to reduce or eliminate circling root formation before they become girdling roots (Appleton 1994). Most of these production techniques involve changes in container design or the use of copper-based coatings on the inside of the container to prohibit root growth. 
Mechanical disruption of circling roots in pot-bound, container-grown trees is a standardized recommendation despite the fact that there is no scientific evidence to support the purported benefits of this practice. Research studies addressing this problem are limited and contradictory conducted primarily using shrubs (Wright and Milbocker 1978; Wade and Smith 1985; Blessing and Dana 1987). The most recent studies show that slicing the root ball from top to bottom in several locations does not increase root growth after planting (Dana and Blessing 1994; Arnold 1996; Gilman et al. 1996). However, it does appear to enhance distribution of regenerated roots in the backfill soil profile (Gilman et al. 1996). It is speculated that this could help establishment by allowing the roots to quickly explore a larger volume of backfill soil. The data are scarce and inconclusive to either support or oppose these mechanical root disruption practices. The research study reported here was designed to assess the effectiveness of mechanical root disruption as a technique for encouraging root growth outside of the original root ball. It was also designed to determine if any one mechanical root disruption practice was better than another in terms of subsequent root development and growth.

\section{MATERIALS AND METHODS}

Thirty Tilia cordata Mill. and 30 Salix alba L. 'Niobe' were planted using a randomized complete block design in June 2003 at the University of Minnesota's TRE Nursery in St. Paul, Minnesota. The T. cordata were grown at the TRE Nursery for 3 years in \#7 containers at which time they were judged to be pot-bound. The $S$. alba 'Niobe' were donated by a midwestern wholesale nursery grower. They were in \#10 containers and were judged to be pot-bound also. For a tree to be considered pot-bound, the root/soil ball had to have encircling woody roots greater than $5 \mathrm{~mm}(0.2 \mathrm{in})$ in diameter dominating the interface between the inside surface of the container and the outside surface of the soil ball, including the bottom surface. Although severely pot-bound, all trees were judged to be healthy.

\section{Field Preparation}

The study site was uncultivated for one growing season under a cover crop of buckwheat (Fagopyrum esculentum Moench). The field was then chisel-plowed to a depth of $61 \mathrm{~cm}(24.4$ in), disked, and finish graded with a tractor-mounted rotary tiller and harrowing rake. The soil is classified as a Waukegan silt loam. Planting rows were laid out as an equilateral triangle-hexagon design with $1.8 \mathrm{~m}$ (4.94 ft) between rows and $2.7 \mathrm{~m}(8.91 \mathrm{ft})$ between trees within the rows.

\section{Tree Preparation}

Trees were pruned once before transplanting to establish a $60 \%$ live crown ratio. The depth to first main-order roots was established on all root/soil balls to ensure proper planting depth (first-order roots at or slightly above the soil line) in the nursery. All root/soil balls were measured at the time of planting to ensure uniformity. Root/soil ball measurements were recorded as follows:

T. cordata: $32 \mathrm{~cm}$ (12.8 in) top diameter, $29 \mathrm{~cm}$ (11.6 in) bottom diameter, $22 \mathrm{~cm}$ (8.8 in) height.

S. alba 'Niobe': $35 \mathrm{~cm}$ (14 in) top diameter, $32 \mathrm{~cm}$ (12.8 in bottom diameter, $30 \mathrm{~cm}$ (12 in) height.

\section{Treatments}

The following mechanical root disruption treatments were applied to the root/soil balls in this study.

\section{Score}

Four (4) vertical slices, each $2.5 \mathrm{~cm}$ (1 in) deep evenly spaced around the root/soil ball with an additional cross-slice of the same depth across the bottom.

\section{Butterfly}

One (1) $15.2 \mathrm{~cm}$ (6.1 in) deep slice centered on the bottom of the root/soil ball with sliced portions splayed apart.

\section{Tease}

Encircling roots "teased" out from the root/soil ball every $15.2 \mathrm{~cm}$ (6.1 in) of circumference using a hay baling hook as the tool.

\section{Control}

No disruption of the root/soil ball.

Each treatment had a total of seven (7) replicates per species. Each control had a total of nine (9) replicates per species.

\section{Planting Out}

The trees were coded by species, treatment, and replicate number and planted out using a randomized complete block design. The diameters of the planting holes were dug to be twice the diameter of the root ball. Treatments were applied and the trees were planted on 23 June through 25 June 2003. On completion of the planting and initial irrigation, T-Tape irrigation drip tape (T-Tape Systems International, T-TAPE TSX Tree \& Vine 500 Model) was laid down the tree's rows. All rows were mulched with 7.6 to $10.2 \mathrm{~cm}$ (3 to 4.1 in) of wood chips to a diameter width of $30.8 \mathrm{~cm}$ (12.3 in). Aisles were then seeded with a chewings fescue (Festuca rubra subsp. commutata) and maintained as a sod aisle.

\section{Maintenance}

Trees were irrigated throughout the growing season with a T-Tape irrigation drip tape to maintain uniform soil moisture (3 to 5 day interval for several hours each time depending on precipitation). The aisles were mowed periodically to maintain a $7.5 \mathrm{~cm}$ (3 in) height on the fescue. Weeds in the mulched rows were controlled using glyphosate herbicide or hand-removed as needed. The trees were pruned 26 May 
2004 to maintain the $60 \%$ live crown ratio. The trees were monitored periodically for insect and disease problems but no treatment was necessary.

\section{Tree/Root Harvest}

All trees were harvested during the week of 11 October 2004. Each tree was cut off $61 \mathrm{~cm}$ (24.4 in) above ground and their species/treatment code marked on the cut surface of the remaining stem. The root systems were harvested with a $0.9 \mathrm{~m}$ $(2.97 \mathrm{ft})$ diameter "Ace of Spades" tree spade and the root ball set to the side of the hole. Harvested root/soil balls were approximately $0.02 \mathrm{~m}^{3}\left(0.7 \mathrm{ft}^{3}\right)$ for the $T$. cordata and 0.03 $\mathrm{m}^{3}\left(1.05 \mathrm{ft}^{3}\right)$ for the $S$. alba 'Niobe', respectively. Soil was washed from the root ball and the roots loosened until the original root/soil ball was exposed. Preplant measurements were used to confirm the dimensions of the original root/soil balls. All roots emerging from the sides of the root/soil balls beyond the original root/soil ball dimensions were pruned, placed in sealable plastic bags, and stored in a refrigerated, walk-in cooler at $4^{\circ} \mathrm{C}\left(39.20^{\circ} \mathrm{F}\right)$. Emergent roots on the bottom of the root/soil balls were harvested in the same fashion and kept separated from the roots harvested from the sides.

\section{Root Evaluation}

Side roots were graded and counted separate from bottom roots. Roots from individual trees were graded into four diameter categories and counted. The size categories were:

Category 1: Less than $5 \mathrm{~mm}(0.20 \mathrm{in})$ diameter.

Category 2: 5.1 to $10 \mathrm{~mm}$ ( 0.20 to $0.40 \mathrm{in})$ diameter.

Category 3: 10.1 to $3 \mathrm{~mm}$ ( 0.40 to $1.12 \mathrm{in})$ diameter.

Category 4: greater than $30.1 \mathrm{~mm}$ (1.20 in) diameter.
Data were subjected to analysis of variance using SPSS (version 7.5 for Windows; SPSS Inc., Chicago, IL). Means were used to separate differences within species and between treatments for root regeneration. Comparisons were made using Fisher's least significant difference at the 5\% level $(P=$ 0.05).

\section{RESULTS AND DISCUSSION}

All trees survived for the duration of the experiment.

The majority of the regenerated roots were in the smallest size category (Table 1). They appear to be growing from the encircling roots and not necessarily from the pruned root surfaces. This supports Struve's (1990) earlier observation that roots circling in a container do not continue to grow in a circle once the tree is planted in the landscape. However, there was no significant difference between mechanical root disruption treatments as compared with the control for the number of roots regenerated within species. Although these fibrous roots may be beneficial for the initial establishment of pot-bound, container-grown trees in landscape, there does not appear to be any inherent advantage in mechanically disrupting the roots of pot-bound, container-grown trees if the objective is to increase the number of radially distributed woody roots in pot-bound, container-grown trees.

Regenerated roots from the bottom of the root/soil ball were more fibrous than woody (Table 1). In contrast to Ellyard's earlier study (1984), scoring of the bottom of the root/ soil balls did not increase the production of vertical roots on the sides of the root/soil balls. In other words, there was no significant difference between mechanical root disruption treatments as compared with the controls for the number of roots regenerated on the bottoms of the root/soil balls within

Table 1. Effect of mechanical root disruption treatments 14 months after planting on root regeneration of the sides and bottoms of pot-bound, container-grown trees ${ }^{2}$.

\begin{tabular}{|c|c|c|c|c|c|c|c|c|}
\hline \multirow[b]{3}{*}{ Treatment } & \multirow{2}{*}{\multicolumn{2}{|c|}{$\begin{array}{l}\text { Mean no. of roots } \\
(<5 \mathrm{~mm} \\
[0.20 \mathrm{in}] \text { diameter })\end{array}$}} & \multirow{2}{*}{\multicolumn{2}{|c|}{$\begin{array}{c}\text { Mean no. of roots } \\
\text { (5.1 to } 10 \mathrm{~mm} \\
[0.20 \text { to } 0.40 \mathrm{in}] \text { diameter })\end{array}$}} & \multirow{2}{*}{\multicolumn{2}{|c|}{$\begin{array}{c}\text { Mean no. of roots } \\
(10.1 \text { to } 30 \mathrm{~mm} \\
[0.40 \text { to } 1.20 \mathrm{in}] \text { diameter })\end{array}$}} & \multirow{2}{*}{\multicolumn{2}{|c|}{$\begin{array}{c}\text { Mean no. of roots } \\
(>30.1 \mathrm{~mm} \\
[1.20 \mathrm{in}] \text { diameter })\end{array}$}} \\
\hline & & & & & & & & \\
\hline & Side & Bottom & Side & Bottom & Side & Bottom & Side & Bottom \\
\hline \multicolumn{9}{|c|}{ Tilia cordata } \\
\hline Score & $236.1 \pm 87.4$ & $79.6 \pm 63.0$ & $7.6 \pm 7.1$ & $4.6 \pm 5.7$ & $1.1 \pm 1.5$ & $0.3 \pm 0.8$ & $0.1 \pm 0.4$ & $0.0 \pm 0.0$ \\
\hline Butterfly & $147.0 \pm 70.1$ & $69.7 \pm 27.1$ & $9.0 \pm 6.7$ & $5.0 \pm 3.0$ & $1.4 \pm 2.0$ & $0.6 \pm 0.8$ & $0.0 \pm 0.0$ & $0.0 \pm 0.0$ \\
\hline Tease & $202.3 \pm 87.4$ & $72.0 \pm 44.1$ & $7.0 \pm 6.6$ & $3.4 \pm 2.9$ & $1.4 \pm 2.2$ & $0.4 \pm 0.8$ & $0.0 \pm 0.0$ & $0.0 \pm 0.0$ \\
\hline Control & $230.2 \pm 28.3$ & $95.6 \pm 42.8$ & $10.6 \pm 0.9$ & $5.9 \pm 4.3$ & $1.3 \pm 1.5$ & $0.0 \pm 0.0$ & $0.0 \pm 0.0$ & $0.0 \pm 0.0$ \\
\hline \multicolumn{9}{|c|}{ Salix alba 'Niobe' } \\
\hline Score & $165.4 \pm 81.7$ & $59.7 \pm 64.0$ & $15.1 \pm 0.2$ & $7.3 \pm 6.9$ & $17.1 \pm 7.5$ & $2.6 \pm 1.8$ & $3.3 \pm 3.6$ & $1.9 \pm 2.9$ \\
\hline Butterfly & $169.1 \pm 33.9$ & $73.4 \pm 72.5$ & $12.4 \pm 5.4$ & $6.3 \pm 2.4$ & $14.4 \pm 8.4$ & $4.1 \pm 3.4$ & $4.0 \pm 2.0$ & $0.3 \pm 0.8$ \\
\hline Tease & $208.1 \pm 89.9$ & $111.1 \pm 6.0$ & $16.7 \pm 0.4$ & $8.6 \pm 3.6$ & $15.6 \pm 8.1$ & $5.7 \pm 5.1$ & $3.1 \pm 3.0$ & $0.1 \pm 0.4$ \\
\hline Control & $230.1 \pm 14.3$ & $111.8 \pm 3.7$ & $15.1 \pm 1.0$ & $9.0 \pm 5.1$ & $13.0 \pm 5.0$ & $5.8 \pm 3.6$ & $3.4 \pm 3.1$ & $0.8 \pm 2.3$ \\
\hline
\end{tabular}

${ }^{z}$ Each value is the mean and standard deviation of seven observations for each treatment within species and nine observations for the controls within species. The treatment descriptions are given in the materials and methods section. There were no significant differences between treatments using Fisher's least significant difference at the $5 \%$ level $(P=0.05)$. 
species in this study. In conclusion, there does not appear to be any inherent advantage in mechanically disrupting the roots of pot-bound, container-grown trees using the methods described in this study if the objective is to increase the number of vertically distributed woody roots in pot-bound, container-grown trees.

The standard recommendation of mechanically disrupting roots of pot-bound, container-grown trees at planting time should not necessarily be abandoned based on the results of this research. More research needs to be done using different species of trees, trees grown for longer periods of time, or other possible factors before we can validate or refute the recommendation of these practices. For example, maybe there is a difference between mechanical disruption methods for pot-bound, container-grown trees with encircling roots less than $5 \mathrm{~mm}$ ( $0.20 \mathrm{in})$ diameter versus trees with encircling roots greater than $5 \mathrm{~mm}$ ( $0.20 \mathrm{in})$ diameter. Answers to questions like this will help to establish research-based recommendations for the proper handling of pot-bound, containergrown trees in the landscape.

Acknowledgments. This research was funded in part by grants from the Minnesota Nursery and Landscape Association Foundation and the Minnesota Turf and Grounds Foundation. The authors express their gratitude to Bailey Nurseries, Inc. for donating some of the trees used in this study.

\section{LITERATURE CITED}

Appleton, B.L. 1993. Nursery production alternatives for reduction or elimination of circling tree roots. Journal of Arboriculture 19:383-388.

- 1994. Elimination of circling tree roots during nursery production, pp. 93-97. In Landscape Below Ground. Watson, G.W., and D. Neely, Eds. Int'l. Soc. Arboric. Savoy, IL.

Arnold, M.A. 1996. Mechanical correction and chemical avoidance of circling roots differentially affect posttransplant root regeneration and field establishment of container-grown Shumard oak. Journal of the American Society for Horticultural Science 121:258-263.

Blessing, S.C., and M.N. Dana. 1987. Post-transplant root system expansion in Juniperus chinensis L. as influenced by production system, mechanical root disruption and soil type. Journal of Environmental Horticulture 5:155-158.

Costello, L., and J.L. Paul. 1975. Moisture relations in transplanted container plants. HortScience 10:371-372.

Dana, M.N., and S.C. Blessing. 1994. Post-transplant root growth and water relations of Thuja occidentalis from field and containers, pp. 98-112. In Landscape Below Ground. Watson, G.W., and D. Neely, Eds. Int'l. Soc. Arboric. Savoy, IL.

Ellyard, R.K. 1984. Effect of root pruning at time of planting on subsequent root development of two species of eucalyptus. Journal of Arboriculture 10:214-216.
Feucht, J.R., and J.D. Butler. 1988. Landscape Management. Van Nostrand. New York.

Flemer, W. 1980. Nursery production of trees in containers. METRIA Proc. 3:15-23.

1982. Successful transplanting is easy. American Nurseryman 145:43-55.

Gilman, E.F., T.H. Yeager, and D. Weigle. 1996. Fertilizer, irrigation and root ball slicing affects Burford holly growth after planting. Journal of Environmental Horticulture 14:105-110.

Gouin, F.R. 1983. Girdling by roots and ropes. Journal of Environmental Horticulture 1:48-50.

- 1984. Updating landscape specifications. Journal of Environmental Horticulture 2:98-101.

Harris, R.W., J.R. Clark, and N.P. Matheny. 2004. Arboriculture: Integrated Management of Landscape Trees, Shrubs, and Vines. 4th Ed. Prentice Hall. Upper Saddle River, NJ.

Holmes, F.W. 1984. Effects on maples of prolonged exposure by artificial girdling roots. Journal of Arboriculture 10: 40-44.

Ingram, D.L., and H. van de Werken. 1978. Effects of container media and backfill composition on the establishment of container-grown plants in the landscape. HortScience 13:583-584.

Siebenthaler, J. 1993. Growing better trees for better landscapes. Southern Nursery Digest 27:36-38.

Struve, D.K. 1990. Root regeneration in transplanted deciduous nursery stock. HortScience 25:266-270.

Struve, D.K., and B.C. Moser. 1984. Root system and root regeneration characteristics of pin and scarlet oak. HortScience 19:123-125.

Wade, G.L., and G.E. Smith. 1985. Effect of root disturbance on establishment of container grown Ilex crenata 'Compacta' in the landscape. SNA Res. Conf. 30:110-111.

Watson, G.W., and E.B. Himelik. 1997. Principles and Practice of Planting Trees and Shrubs. Int'l. Soc. Arboric. Savoy, IL.

Whitcomb, C.E. 1984. Container design: Problems and progress, pp. 107-130. In Plant Production in Containers. Lacebark Publications, Stillwater, OK.

Wright, R.D., and D.C. Milbocker. 1978. The influence of container media and transplanting technique on the establishment of container grown Rhododendron cv. 'Hershey Red' in landscape plantings. SNA Res. Conf. 5:1-7.

Patrick J. Weicherding (corresponding author)

Regional Extension Educator and Professor

University of Minnesota Extension Service

Andover Regional Center

550 Bunker Lake Boulevard NW

Andover, MN 55304, U.S.

weich002@umn.edu 
Chad P. Giblin

Scientist

Department of Horticulture Science

University of Minnesota

384 Alderman Hall

1970 Folwell Avenue

St. Paul, MN 55108, U.S.

Jeffrey H. Gillman

Associate Professor

Department of Horticulture Science

University of Minnesota

164 Alderman Hall

1970 Alderman Hall

St. Paul, MN 55108, U.S.

David L. Hanson

Research Specialist

College of Natural Resources

University of Minnesota

220C Green Hall

1530 Cleveland Avenue

St. Paul, MN 55108, U.S.

Gary R. Johnson

Professor of Urban and Community Forestry

Department of Forest Resources

University of Minnesota

101 E Green Hall

1530 Cleveland Avenue

St. Paul, MN 55108, U.S.

Résumé. Des Tilia cordata Mill. et des Salix alba L. 'Niobe' produits en pot avec des racines cerclantes ont été mis en terre dans un sol fait d'un loam limoneux de classe Waukegan en juin 2003 à la pépinière TRE de l'Université du Minnesota à Saint-Paul. Préalablement à la plantation, les mottes de racines des plants produits en contenant ont été brisées mécaniquement au moyen de l'une des trois méthodes standards de taille des racines recommandées pour corriger les problèmes de racines cerclantes: coupe en ligne droite, taille papillon ou peignage. Les mottes de racines du groupe témoin ont été laissées intactes. Les arbres ont été récoltés en octobre 2004. Les racines qui ont poussé hors de la motte originale ont été dénombrées et mesurées en fonction de leur croissance en diamètre afin de déterminer l'efficacité des techniques de taille des racines pour encourager la croissance racinaire hors de la motte originale. Tous les traitements effectués ont résulté en un accroissement de la croissance en racines fibreuses mais aucune des méthodes mécaniques de taille des racines ne s'est avérée supérieure aux arbres du groupe témoin dont les mottes originales ont été laissées intactes.

Resumen. Tilia cordata Mill. y Salix alba L. 'Niobe' fueron plantados en suelo franco-arcilloso en Waukegan en Junio, 2003 en el vivero de la Universidad de Minnesota en St. Paul, Minnesota. Antes de la plantación, las bolas de las raíces de las plantas con contenedor fueron desmenuzadas mecánicamente usando una de las tres prácticas estándar de podas de raíz recomendadas para corregir raíces enrolladas. Las bolas de las raíces en los controles fueron dejadas intactas. Los árboles fueron cosechados en Octubre, 2004. Las raíces que crecieron más allá de la bola original fueron contadas y medidas para el crecimiento en diámetro para evaluar la efectividad de las técnicas de poda en favorecer el crecimiento de las raíces afuera de la bola original. Todos los tratamientos dieron como resultado un incremento en el crecimiento de raíces fibrosas pero ningún método mecánico fue significativamente mejor que las bolas de raíces dejadas intactas.

Zusammenfassung. Im Juni 2003 wurden in der Baumschule der Universität von Minnesota in St. Paul, Minnesota getopfte Tilia cordata und Sali x alba in einen Ton-Lehn-Boden verpflanzt. Vor dem Pflanzen wurden die Wurzelballen der Containerpflanzen mechanisch zerrupft, wobei je eine der drei empfohlenen Standartmethoden zur Entwirrung von Wurzelballen verwendet wurden: Schlitzen, Schmetterlingsschnitt und Rupfen. Die Wurzelballen in der Kontrolle blieben unberührt. Die Bäume wurden 2004 im Oktober geerntet. Die Wurzeln, die neben dem ursprünglichen Wurzelballen gewachsen waren, wurden gezählt und ihre Größe gemessen, um die Effektivität der Schnittmethoden zur Anregung des Wurzelwachstums zu bestimmen. Alle Methoden führten zu einem vermehrten Feinwurzelwachstum, aber keine war besser als die nicht behandelten Kontroll-Wurzelballen. 